\title{
鉄鋼溶接部における硫化物の挙動之凝固割れ（第8報）*
}

一N 入り高張力鋼の溶接凝固割れ感受性についての検討一

\author{
仙田富男** 松田福久** 中川博二** 浜中孝道**
}

\section{Sulphide and Its Effect on Solidification Cracking in Weld Metal of Steel (Report 8)*}

-Weld Solidification Crack Susceptibility of High Tensile

Steel Containing Nickel--

by Tomio Senda**, Fukuhisa Matsuda***, Hiroji Nakagawa**** and Takamichi Hamanaka****:

\begin{abstract}
Effects of sulphur, nickel, carbon, manganese and phosphorus on weld solidification crack susceptibility of various commercial and tentative high tensile steels (tensile strength: $50-100 \mathrm{~kg} / \mathrm{mm}^{2}$ class) have been investigated using the Longi-Varestraint test.

Main conclusions obtained are as follows:

1) Sulphur, even at $0.005 \%$ level, remarkably increases the solidification crack susceptibility.

2) Nickel and carbon promote the detrimental effect of sulphur '(and phosphorus).

3) Even in the steel containing nickel and/or crabon, the high crack susceptibility induced by sulphur can be lowered by increasing the manganese content. And the manganese content required agrees with the value deduced theoretically in the previous paper. This is given by the condition that $\mathrm{Mn}^{5} \mathrm{~S}$ is larger than $310-560$.

4) Phosphorus also remarkably increases the crack susceptibility in the steel containing nickel (and carbon).
\end{abstract}

\section{1. 緒 言}

著者らは前報1において，S含有量が寒用鋼に比しや や多い Fe-S-Mn-Ni 4 元系合金を用いた基脴的研究 で, Ni は S の悪影響を助長して溶接凝固割れ感受性を いちじるしく增大させるととを明らかにした。 また Ni を $2 \sim 10 \%$ 含有する溶接金属においても $\mathrm{Mn}$ 含有量を 増加させるととにより，凝固割机感受性を $\mathrm{Mn}^{3} / \mathrm{S}$ が 6.7 以上の Fe-S-Mn 系合金と同程度にまで低下させるとと が可能なととを示した。 そしてさらに任意の S 含有量に 対して凝固割征受性を低下させるに必要な $\mathrm{Mn}$ 含有 量を求网関係式を検討した。

いっぽう最近の溶接用高張力鋼の発達はいちじるし く, 引張強さ $80 \sim 100 \mathrm{~kg} / \mathrm{mm}^{2}$ 級の高強度のむのが出

\footnotetext{
* 原稿受付 昭和49年 2 月21日（49年第55回溶接冶金研究委員会下层 步)

** 正 員大服大学工学部 Member, Faculty of Engineering, Osaka University

*** 正 員 大阪大学容接工学研乫所 Member, Welding Research Institute of Osaka University

***** 学 生員大陑大学大学院 Student Member, Postgraduate Corse of Osaka University
}

現し始めており，てれらには強度ならびに勒性を高める 目的で Ni が1〜2\%以上添加されていることが多い. またこれらの鋼材の S 含有量は一般にかなり低く制限さ れている，しかしてれらの高強度の高張力鋼では溶接金 属で発生するミクロな凝固割れが，低荷重破壊や水菜に 起因するマクロな低温割れの発生源になるともいわれて おり，そのため最近とれらの鋼材の凝固割机感受性が重 要視されるようなってきている.

そてで本報告では，引張強さ $50 \sim 100 \mathrm{~kg} / \mathrm{mm}^{2}$ 級の実 用高張力鋼ならびに試作の $\mathrm{Ni}$ 入り高張力錀を約 40 種類 用いて，主として溶接凝固割れ感受性におよぼす $\mathrm{S}, \mathrm{Ni}$ および Mn の影響について検討を行なった。 とくにS とMn に関しては，前報】で検討した凝固割机感受性を 低下させるに必要な $\mathrm{S}$ と $\mathrm{Mn}$ 量の関係式について，実験 的確認を行なった，さらに，高強度の高張力鋼における 含有量は一般任少ないが $\mathrm{Ni}$ 之同様汇凝固割れ感受性を 増大させるCの影響，ならびに S ととあに凝固割れの主 原因と考えられているPの影響についても一部検討を行 なった。なお疑固割れ試験には Longi-Varestraint 試験 法を用いた。 


\section{2. 使用材料および実験方法}

\section{2-1 使用材料およひ凝固割れ試験方法}

使用した材料の化学組成を Table 1 にまとめて示す が，乙れらは市販の溶接用高張力鋿 HT-50 (SM50), HT-60 および HT-80，ならびに試作の Ni 入り高張力 鍓 HT-100, HY-110 および HY-130 の菜材, さらに HY-110 と HY-130 亿肉盛を行なったあのである。肉 盛には手動アークあるいは MIG アーク溶接を用い，肉 盛の厚さは約 $6 \mathrm{~mm}$ で凝固割㣗試験時の溶込み深さよ
りあ大きくなるようにした，各材料の大きさは 350 長 $\times$ 50 幅 $\times 12 \mathrm{~mm}$ 厚である. Table 1 でWの記号をつけたる のが肉盛を行なった材料を示している。

疑固割れ試験飞は Longi-Varestraint 試験法を用い た.これは Savage らが考案した Varestraint 試験法2 之同一のあのであるが，著者らが考案した Trans 型の あの と䟝するために “Longi一”をつけた。凝固割 れ感受性の検討には，Trans.Varestraint 法が溶接金 属中の縦割れを明りように発生させるために適している

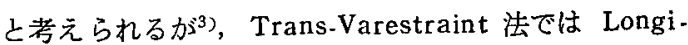

Table 1 Chemical compositions of materials used

\begin{tabular}{|c|c|c|c|c|c|c|c|c|c|c|c|}
\hline \multirow{2}{*}{ Type } & \multirow{2}{*}{ Material } & \multicolumn{10}{|c|}{ Composition (wt. $\%$ ) } \\
\hline & & $\mathrm{C}$ & $\mathrm{Si}$ & $\mathrm{Mn}$ & $\mathbf{P}$ & $\mathrm{S}$ & $\mathrm{Cu}$ & $\mathrm{Ni}$ & $\mathrm{Cr}$ & Mo & $\mathrm{v}$ \\
\hline $\begin{array}{r}\mathrm{HT}-50 \\
\text { (SM50) }\end{array}$ & T5 & 0.16 & 0.49 & 1.39 & 0.016 & 0.008 & - & - & 0.007 & 0.01 & - \\
\hline $\mathrm{HT}-60$ & T6 & 0.20 & 0.13 & 1.15 & 0.013 & 0.012 & 0.010 & 0.014 & 0.008 & - & 0.008 \\
\hline \multirow{2}{*}{ HT-80 } & T8-1 & 0.15 & 0.27 & 0.88 & 0.015 & 0.004 & 0.28 & 0.016 & 0.52 & 0.36 & 0.031 \\
\hline & T 8-2 & 0.096 & 0.30 & 0.77 & 0.005 & 0.005 & 0.25 & 1.16 & 0.38 & 0.41 & 0.025 \\
\hline \multirow{17}{*}{ HT-100 } & $T 10-1$ & 0.09 & 0.30 & 0.79 & 0.009 & 0.007 & 0.22 & 0.89 & 0.44 & 0.38 & 0.04 \\
\hline & $\mathrm{T} 10-2$ & 0.14 & 0.24 & 0.79 & 0.007 & 0.010 & 0.03 & 1.95 & 0.54 & 0.54 & 0.06 \\
\hline & $T 10-3$ & 0.13 & 0.21 & 0.73 & 0.003 & 0.005 & $<0.01$ & 1.97 & 0.54 & 0.54 & 0.06 \\
\hline & $\mathrm{T} 10-4$ & 0.040 & 0.25 & 0.80 & 0.008 & 0.007 & 0.015 & 2.01 & 0.60 & 0.60 & 0.06 \\
\hline & $\mathrm{T} 10-5$ & 0.10 & 0.30 & 0.79 & 0.003 & 0.005 & $<0.01$ & 2.01 & 0.56 & 0.55 & 0.06 \\
\hline & T 10- 6 & 0.10 & 0.27 & 0.83 & 0.006 & 0.010 & 0.03 & 2.01 & 0.55 & 0.55 & 0.06 \\
\hline & T 10- 7 & 0.08 & 0.24 & 0.50 & 0.008 & 0.007 & 0.21 & 3.31 & 0.04 & 0.01 & 一 \\
\hline & T $10-8$ & 0.10 & 0.23 & 0.98 & 0.006 & 0.006 & - & 4.00 & - & - & - \\
\hline & T $10-9$ & 0.039 & 0.25 & 0.80 & 0.012 & 0.010 & 0.015 & 5.01 & 0.60 & 0.60 & 0.06 \\
\hline & T 10-10 & 0.041 & 0.28 & 0.83 & 0.011 & 0.021 & 0.02 & 5.05 & 0.65 & 0.63 & 0.07 \\
\hline & T 10-11 & 0.09 & 0.11 & 0.79 & 0.009 & 0.009 & 0.01 & 9.04 & 0.64 & 0.64 & 0.06 \\
\hline & $\mathrm{T} 10-12$ & 0.08 & 0.19 & 0.79 & 0.008 & 0.009 & 0.02 & 9.05 & 0.64 & 0.64 & 0.06 \\
\hline & T $10-13$ & 0.14 & 0.24 & 0.77 & 0.010 & 0.009 & 0.04 & 2.04 & 0.53 & 0.53 & 0.06 \\
\hline & T 10-14 & 0.14 & 0.20 & 0.77 & 0.016 & 0.009 & 0.04 & 1.94 & 0.53 & 0.53 & 0.07 \\
\hline & T $10-15$ & 0.13 & 0.21 & 0.77 & 0.030 & 0.009 & 0.03 & 1.96 & 0.53 & 0.53 & 0.06 \\
\hline & T 10-16 & 0.09 & 0.21 & 0.80 & 0.017 & 0.009 & 0.03 & 1.96 & 0.58 & 0.53 & 0.08 \\
\hline & T 10-17 & 0.09 & 0.25 & 0.76 & 0.034 & 0.009 & 0.03 & 1.96 & 0.53 & 0.55 & 0.07 \\
\hline \multirow{16}{*}{ HY -110} & Y11-1 & 0.094 & 0.30 & 0.60 & 0.005 & 0.006 & - & 3.30 & 0.78 & 0.40 & 0.07 \\
\hline & Y 11-2 & 0.11 & 0.22 & 0.75 & 0.004 & 0.005 & - & 3.33 & 0.80 & 0.44 & 0.04 \\
\hline & $Y 11-3$ & 0.11 & 0.26 & 0.70 & 0.007 & 0.007 & - & 3.47 & 0.70 & 0.53 & 0.02 \\
\hline & Y 11-4 & 0.065 & 0.20 & 0.50 & 0.004 & 0.006 & $-'$ & 4.07 & 0.55 & 0.52 & 0.06 \\
\hline & Y 11-5 & 0.07 & 0.50 & 0.50 & 0.003 & 0.006 & - & 4.14 & 0.53 & 0.06 & 0.06 \\
\hline & Y $11 W-1$ & 0.076 & 0.36 & 1.69 & 0.003 & 0.002 & 0.25 & 2.24 & 0.75 & 0.56 & - \\
\hline & $Y 11 W-2$ & 0.069 & 0.37 & 1.38 & 0.002 & 0.002 & 0.25 & 2.31 & 0.09 & 0.47 & - \\
\hline & Y11W- 3 & 0.063 & 0.36 & 1.37 & 0.002 & 0.002 & 0.32 & 2.31 & 0.52 & 0.47 & - \\
\hline & Y11W- 4 & 0.076 & 0.36 & 1.70 & 0.002 & 0.003 & 0.29 & 2.24 & 0.52 & 0.46 & 一 \\
\hline & $\mathrm{Y} 11 \mathrm{~W}-5$ & 0.075 & 0.38 & 1.76 & 0.001 & 0.003 & 0.24 & 1.93 & 0.51 & 0.64 & - \\
\hline & Y $11 W-6$ & 0.063 & 0.37 & 1.73 & 0.001 & 0.002 & 0.23 & 2.28 & 0.52 & 0.50 & 一 \\
\hline & Y11W- 7 & 0.065 & 0.37 & 1.65 & 0.002 & 0.002 & 0.24 & 2.23 & 0.12 & 0.48 & - \\
\hline & $Y 11 W-8$ & 0.071 & 0.26 & 1.43 & 0.003 & 0.004 & 0.38 & 2.50 & 0.85 & 0.70 & - \\
\hline & Y $11 W-9$ & 0.065 & 0.25 & 1.30 & 0.003 & 0.007 & - & 2.65 & 0.53 & 0.61 & 一 \\
\hline & $\mathrm{Y} 11 \mathrm{~W}-10$ & 0.068 & 0.32 & 1.28 & 0.001 & 0.002 & 0.27 & 2.66 & 0.52 & 0.40 & - \\
\hline & $Y 11 W-11$ & 0.05 & 0.47 & 1.10 & 0.003 & 0.004 & 0.04 & 2.67 & 0.76 & 0.35 & - \\
\hline \multirow{6}{*}{ HY -130} & Y 13-1 & 0.09 & 0.26 & 0.50 & 0.007 & 0.006 & - & 5.08 & 0.63 & 0.50 & 0.31 \\
\hline & Y13-2 & 0.08 & 0.28 & 0.46 & 0.003 & 0.005 & - & 5.18 & 0.56 & 0.53 & 0.05 \\
\hline & Y $13 W-1$ & 0.062 & 0.48 & 1.57 & 0.005 & 0.004 & - & 2.57 & 0.93 & 0.56 & - \\
\hline & $Y 13 W-2$ & 0.085 & 0.32 & 1.54 & 0.003 & 0.002 & 0.30 & 3.22 & 0.86 & 0.62 & - \\
\hline & Y $13 W-3$ & 0.053 & 0.53 & 1.11 & 0.004 & 0.007 & 0.15 & 3.28 & 0.48 & 0.84 & - \\
\hline & $Y 13 W-4$ & 0.08 & 0.23 & 1.19 & 0.004 & 0.004 & - & 3.30 & 0.88 & 0.70 & - \\
\hline
\end{tabular}


Varestraint 法に比し大きな試験片を必要とする．しか し本研究のように多数の試作鋼を検討する場合には大き な試験片を作製することは困難である．またすでに HY -80など実用の高張力鋼の溶接において経験されたミク 口割れは横割れである。したがっててのような割れに対 する感受性を検討するには Longi-Varestraint 法が適 当とも考えられる．乙のような理由も加味して次節で一 部の材料に対して Longi-Varestraint 法と TransVarestraint 法の試験結果を比較検討したうえで, LongiVarestraint 法を使用した.

Longi-Varestraint 試験法の詳細は Savage らの報 告2)之同様である. すなわち, その外観を Photo. 1 に

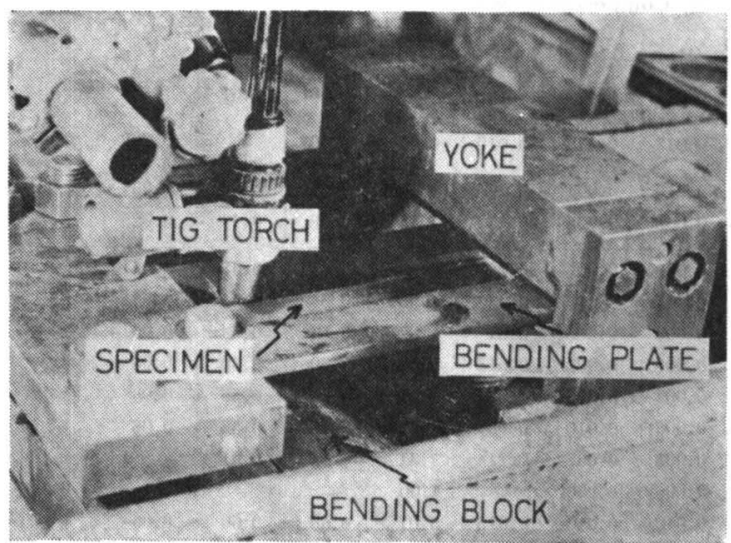

Photo. 1 Close-up view of the Longi-Varestraint apparatus.

示すが, まず試験片を装置に片持ちばり式に固定する. つぎに TIG アークにより試験片の長手方向にヨーク (Yoke）側から固定した側に向かってビード溶接を行な う. そしてその途中で空気シリンダーに直結したヨーク により試験片を曲げブロック (Bending block) に沿っ て急激に曲げる．とのとき試験片の高温部にのみ変形が 集中しないように曲げ添加板 (Bending plate, 板厚 6 $\mathrm{mm}$, 幅 $35 \mathrm{~mm} 2$ 枚) を付加しておく. アークは試験 片を曲げた後むしばらく続けて止める. 試験片の長手方 向の付加ひずみ $\varepsilon(\%)$ は, 曲げブロックの曲率半径を $R(\mathrm{~mm})$, 板厚を $T(\mathrm{~mm})$ とすると近似的につぎのよう に与えられる.

$$
\varepsilon=T / 2 R \times 100(\%)
$$

凝固割れ試験時の溶接条件は, 溶接速度 $100 \mathrm{~mm} / \mathrm{min}$, 溶接電流 $300 \mathrm{~A}$, アーク電圧 $17 \sim 21 \mathrm{~V}$ である.なお, Longi-Varestraint 法と Trans-Varestraint 法の比較 をな行うときには上記の試験条件とはやや異なる条件を 用いた. すなわち, 試験片としては $16 \mathrm{~mm}$ 厚の HT-50 (SM50) を用い, 溶接条件としては $150 \mathrm{~mm} / \mathrm{min}, 25$ ，

\section{A， 17〜20 V を用いた.}

また凝固割れ試験により得られる最大割れ長さを凝固 脆性温度領域 (Solidification brittleness temperature range, BTR $)^{3}$ に換算するために，溶接時の溶接部中央 の温度変化を測定した．これには，W/W $+26 \% \operatorname{Re}$ 熱電 対 $(0.5 \mathrm{~mm} \phi)$ および自動平衡型ペンレコーダーを使用 した.

\section{2-2 Longi-Varestraint 試験法と Trans- Varestraint 試験法の比較}

凝固割れ感受性を評価するうえで, 凝固脆性温度領域 (BTR) が重要な值であると考えられている33).この BTR の值は, Trans-Varestraint 試験法では溶接部中央で発 生する「最大割れ長さ」と溶接部中央の温度分布を測定 しててれらを対応させることにより求めることができ る.しかし Longi-Varestraint 試験法ではひずみが溶接 線方向に与えられるため, 最大の割れは Photo. 2 に示

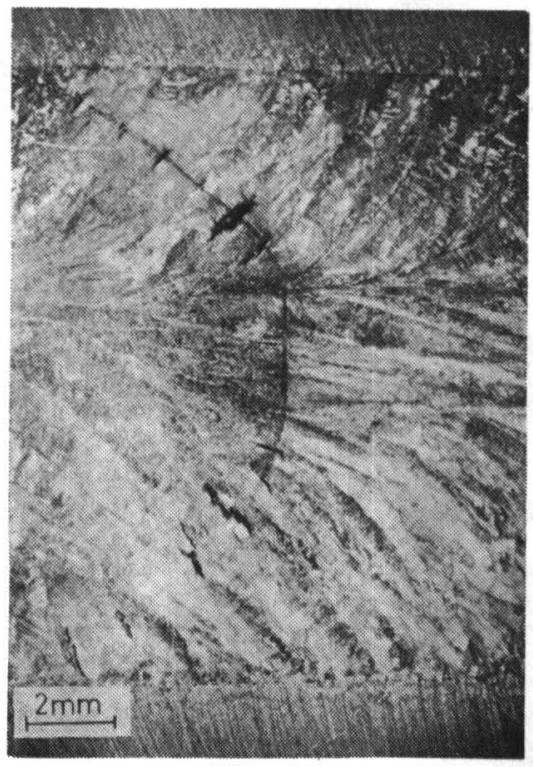

Photo. 2 General appearnce of solidification crack in weld metal tested by LongiVarestraint method.

すように溶接部中央では発生せず，溶接部中央と溶融境 界の中間付近で溶接線方向と約 $45^{\circ}$ の方向に発生する.

そとで Longi-Varestraint 法で得られる最大割れ長さ が B T Rに対応させることができるかどうかについて確 認を行なうために, Longi-Varestraint 法と TransVarestraint 法における最大割れ長さの対応について検 討を行なった. その結果をFig. 1に示す,Fig. 1 によれ ば最大割れ長さは, Longi-Varestraint 法では約 3\%以 上の付加ひずみで一定となり，いっぽう Trans-Varestraint 法では約 $1 \%$ 以上の付加ひずみで一定となる，そ 


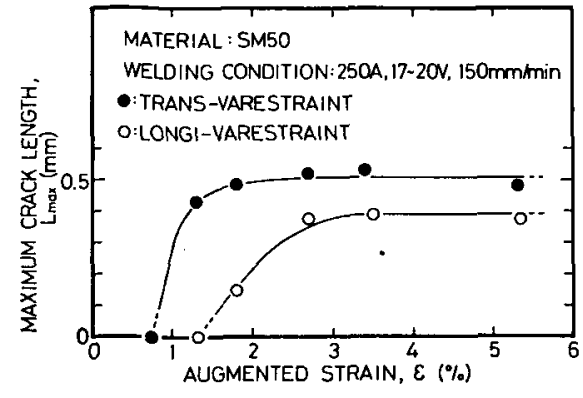

Fig. 1 Comparison in maximum crack length between Trans- and Longi-Varestraint tests.

して一定となった最大割れ長さは Longi-Varestraint 法ではTrans-Varestraint 法の約尔倍の大きさになって いる，ての約 $4 / 5$ とう比はつぎのように説明できる．す なわちTrans-Varestraint 法では一般に数個以上の凝固 割れがBTRに対応する溶接リップル間で発生するが3), この溶接リップルの間隔は溶接部中央で最も大きく，溶 融境界に近づくにつれ小さくなるため，割れ長さもリッ プル間隔と同一の傾向にある。 そして溶接部中央と溶融 境界の中間付近のリップル間隔は溶接部中央の約 $4 / 5$ 倍の 大きさであった.

したがって Longi-Varestraint 法では，最大割れ長さ が一定となる付加ひずみ（約 $3 \%$ 以上）を与え，その之 きの最大割れ長さを $5 / 4$ 倍した值が BTR に対応すること になると考えられる。

\section{3. 実酫結果および考察}

\section{3-1 S の影䟞}

著者らはこれまでの報告において，硫化物の観察を容 易にする目的ならびに疑固割れにおよぼすの効果を顕 著にする目的で， S 含有量が実用鋼に比しやや多い材料

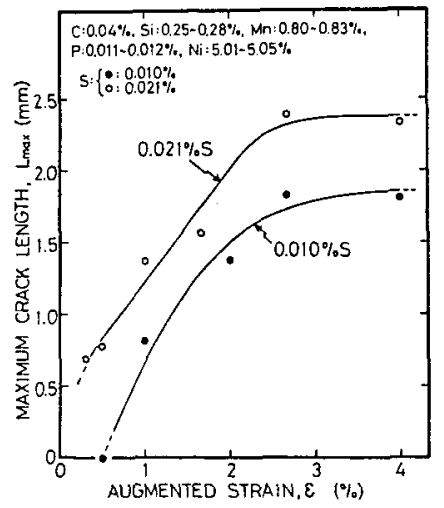

Fig. 2 Effects of sulphur content on the relation between augmented strain and maximum crack length.
を用いてきた。そこで．まず害用鍓と同程度のS含有量 におけるSの勃果について検討を行なった，その結果を Fig. 2 に示す. Fig. 2 は付加ひずみと最大割れ長さの 関係を示したすのであり， S 含有量としては最近の実用 高張力鋼の平均に相当すると考えられる $0.010 \%$ ，およ び実用鋼としては上限に近い $0.021 \% の 2$ 種類を選んだ. $\mathrm{Ni}$ は約 $5 \%$ 含有しており，また他の元素の含有量も図 の上部に示すようにほとんど同一である．Fig. 2 亿よれ ば $0.021 \% \mathrm{~S}$ の試料が各付加ひずみに招ける最大割れ長 さが大きく，また割れが発生する最低の付加ひずみす小 さい，てのようにSは実用鋼程度の含有量においても疑 固割れ感受性に対する悪影響が顕著である.

\section{3-2 Ni の影䈏}

Fig. 3 亿 Ni 量と付加ひずみ 4 \%時の最大割れ長さと の関係を示す．C量やその他の元素量は四の上部に示す ようにほぼ一定である．Fig. 3 亿よれば最大割れ長さは

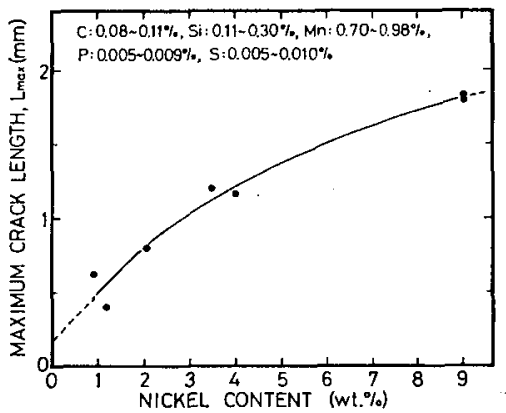

Fig. 3 Relation between nickel content and maximum crack length.

$\mathrm{Ni}$ 量とと李に增加していく，言いかえれば疑固脆性温 度領域（BTR）は $\mathrm{Ni}$ 量ととむに堌加しており，てれは 前報1で述べた S 含有量のやや高い Fe-S-Mn-Ni 系合 金での結果とよく一致している.

また Fig. 3 の最大割れ長さを Ni 含有量が 0 の位置 にまで外挿すると，Cを $0.08 〜 0.11 \%$ 含有した場合の最 大割れ長さ約 $0.2 \mathrm{~mm}$ が得られることになるが，てれは BTR 亿換算すると約 $30^{\circ} \mathrm{C}$ となる．そして Fig. 3 で用 いた材料の $\mathrm{Mn}^{3} / \mathrm{S}$ はすべて 6.7 以上であった. いっぽ う第 5 報4の結果によればC 量が $0.12 \%$ 以下の低炭素鐝 溶接金属の疑固割れ感受性はその $\mathrm{Mn}^{3} / \mathrm{S}$ が6.7以上の上 き非常に小さくなり，そのときの BTR は $30 \sim 40^{\circ} \mathrm{C}$ で ある. したがって Fig. 3 の外㨉值は第 5 報4 の結果と よく対応している，乙れらのととより，Fig. 3 の組成の 範囲では $1 \sim 2 \%$ 程度の $\mathrm{Ni}$ 6凝固割れ感受性を增大さ せることがわかる。

\section{3-3 C の影幚}

前報〉では $\mathrm{Ni}$ の影響を検討するとともにCを約 $0.2 \%$ 


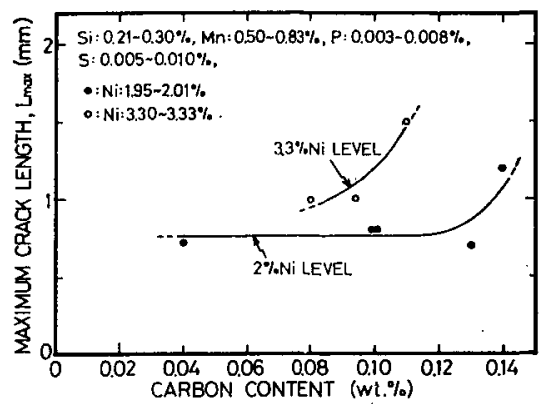

Fig. 4 Relation between carbon content and maximum crack length.

含有する Fe-S-Mn-C 4 元系合金を用いて，凝固割れ感 受性を増大させる C の効果を明らかにした。 しかし Ni 入り高張力鋼では C 含有量は一般に低い。そこでこの上 うに Ni を含有した状態におけるCの影響について検討 を行なった. まず Fig. 4 にC 量之付加ひずみ $4 \%$ 時の 最大割れ長さとの関係を示す. Fig. 4 には Ni 量が $2 \%$ レベルの場合と， $3.3 \%$ レベルの場合を示した. まず2 \% Ni レベルの場合にはC量が約 $0.13 \%$ 以下では Cの影 響はとくに認められないが，約 $0.13 \%$ 以では Cは最大 割れ長さを増加させる. いっぽう $3.3 \% \mathrm{Ni}$ レベルでは 最大割れ長さは $2 \% \mathrm{Ni}$ レベルに比しいずれる大きく， また $0.11 \%$ C程度においてもCは最大割れ長さを增大さ せている.

Fig. 3 と Fig. 4 の結果,ならびにCと Ni はその能 力の程度は異なっていてもいずれも S(および P) の分 配係数の小さいr相の安定化元素であることを考える 之， Cと Ni は凝固割れ感受性に対して加算的な勃果を むっているととが推定される，そこで $\mathrm{Fe}-\mathrm{C}$ 系状態図 ${ }^{5)}$ と $\mathrm{Fe}-\mathrm{Ni}$ 系状態図 ${ }^{6}$ の包晶点における $\mathrm{C}$ と $\mathrm{Ni}$ の重量 \%の比をとるととによりて相を形成する能力を比較す

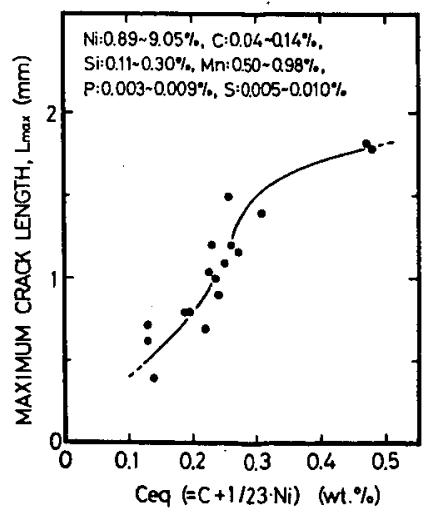

Fig. 5 Relation between crabon equivalent $\left(\mathrm{C}_{\mathbf{e q}}\right)$ and maximum crack length.
れば，Ni の能力はCの約 $1 / 23$ となる。乙れについては Borland ${ }^{7)}$, Marshal1 ${ }^{8)}$, 和田 ${ }^{9)}$ も, 値は少し異なるが， 同様の評価を行なっている，したがって次式に示す宸素 当量 (Ceq) を考元るととができる.

$$
\mathrm{Ceq}=\mathrm{C}+1 / 23 \cdot \mathrm{Ni}(\mathrm{wt} . \%)
$$

(2)式を用いて Fig. 3 と Fig. 4 の結果ならびにその他 の二，三の測定值をまとめて示したものが Fig. 5 であ る. Fig. 5 によれば、ばらつきは多少あるが， C 之 $\mathrm{Ni}$ の加算的勃果は ( 2 )式により比較的よく表わされている あのと考元られる.（2)式の Ni の係数についてより詳 紐に検討するには，測定值を多くすることならびに $\mathrm{Mn}$ 量， S量などの他元菜量をよりいっそう一定にするとと が必要であり, 今後の倹討に待ちたい.

\section{3-4 S ट Mn の相互効果}

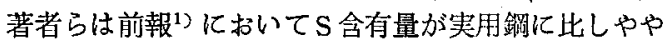
多い $\mathrm{Fe}-\mathrm{S}-\mathrm{Mn}-\mathrm{Ni}$ 於よび $\mathrm{Fe}-\mathrm{S}-\mathrm{Mn}-\mathrm{C}$ 系合金を用い

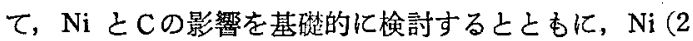
〜 10\%) あるいは C $(0.2 \%)$ を含有する溶接金属に対し て凝固割れ感受性を低下させるに必要な $\mathrm{S}$ 量と $\mathrm{Mn}$ 量 の一般的関係について理論的な検討を行なった。 そして その結果は Fig. 6 のように表わすことができた. Fig. 6

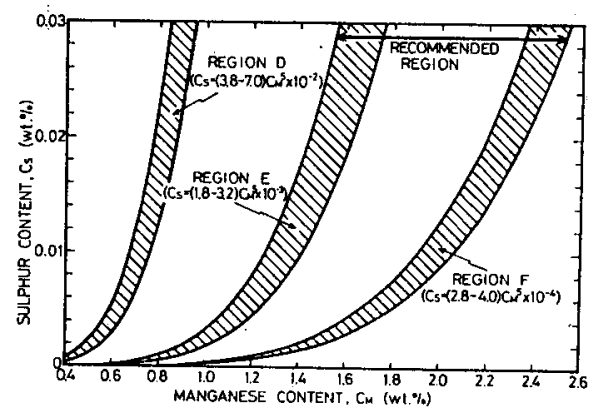

Fig. 6 Theoretically deduced relation among sulphur, manganese contents and solidification crack susceptibility. The crack susceptibilities in the regions $\mathrm{D}, \mathrm{E}$ and $\mathrm{F}$ are high, comparatively low and very low, respectively.

は横軸䎲 Mn 量, 縦軸に S 量をとったものであり，領域 Dは凝固割れ感受性が非常に高い領域，領域 $\mathrm{E}$ は凝固割 れ感受性が比較的低下する領域，さ引に領域 $\mathrm{F}$ は凝固割 れ感受性が 6.7 以上の $\mathrm{Mn}^{3} / \mathrm{S}$ をもつ $\mathrm{Fe}-\mathrm{S}-\mathrm{Mn}$ 系合金 亡同程度にまで低下する領域である。，そして領域 D,E および $\mathrm{F}$ は， $\mathrm{Mn}$ 量を $\mathrm{C}_{\mathrm{M}}, \mathrm{S}$ 量を $\mathrm{C}_{\mathrm{S}}$ とすれば図中の 関係式で表わすととができるが，領域 $\mathrm{E}$ と $\mathrm{F}$ 亿つてそ の関係式を $\mathrm{Mn}^{5} / \mathrm{S}$ の形で表わせばそれぞれ(3)および (4)式のように書ける.

$$
\mathrm{Mn}^{5} / \mathrm{S}=310 \sim 560
$$


$\mathrm{Mn}^{5} / \mathrm{S}=2500 \sim 3600$

そして領域 $\mathrm{E} と \mathrm{~F}$ 間を推奖領域とし, 領域 $\mathrm{F}$ に近いほ ど望ましいものと考えた。

そこで上記の領域が S 含有量の低い高張力鎡に対して も適用できるかどうかについて検討を行なった，その絬 果を Fig. 7 に示守. 図中の测定点に記した数字は付加

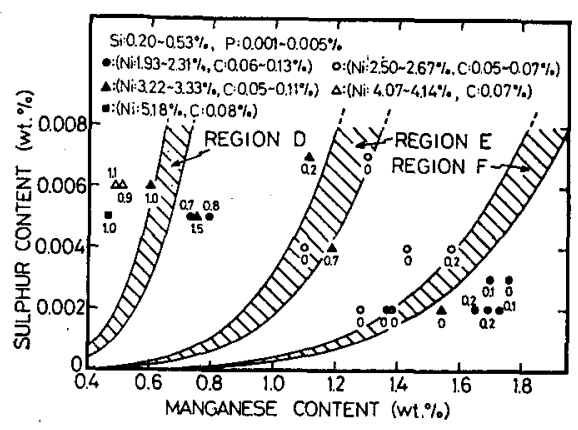

Fig. 7 Relation among sulphur, manganese contents and maximum crack length $(\mathrm{mm})$ obtained from Varestraint test.

ひずみ $4 \%$ 洔の最大割れ長さ $(\mathrm{mm})$ を示し，また各测 定点の印は $\mathrm{Ni} レ$ レ゙ル（およびCレベル）により分類し たものである。なお $\mathrm{P}$ 量は，次節で示すように Ni ある いはC量（あるいは Ceq）の高い溶接金属では凝固割れ 感受性におよぼすPの影響が算視できなくなるため, $0.005 \%$ 以下に制限した．Fig. 7 によれば領域Dの付近 では最大割れ長さはいずれも $1 \mathrm{~mm}$ 前後と大きく（BTR に換算して約 $150^{\circ} \mathrm{C}$ ), 凝固割札感受性が非常に高い.

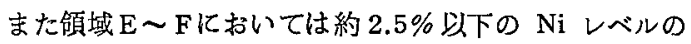
ものは最大割れ長さがいずれも $0 \sim 0.2 \mathrm{~mm}$ と小さく, 凝固割れ感受性が非常に低下している。しかし約 $3.3 \%$ $\mathrm{Ni}$ レベルでは領域 Eに括いて最大割れ長さのやや大き い屯の $(0.7 \mathrm{~mm})$ が認められる. Ni レベルがさらに高 いあのに対しては十分な検討はできなかったが，上記の 結果より前報1)で理論的に検討し，推奖した領城 $\mathrm{E} \sim \mathrm{F}$ はじ山う分に罗当性のあるあのと考えられる。

なおまた Fig. 7 の結果は，Sが0.005\%前後の低い含 有量においても凝固割れ感受性にいちじるしく影響をお

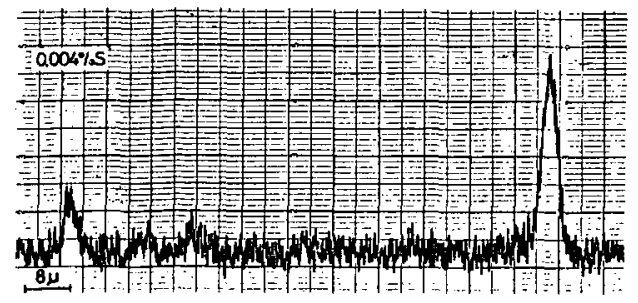

Fig. 8 Microsegregtion of sulphur in weld metal of Y11W-8 analyzed with EPMA.
よぼすことを示しているてとになるが，このことはSの ミクロ偏析を EPMA で分析した結果からす理解でき る.すなわち Fig. 8 は $2.5 \% \mathrm{Ni}, 0.071 \% \mathrm{C}, 0.004 \%$ $\mathrm{S}$ の枋料 (Y11W-8) の溶接金属に対して EPMA で線 分析を行なった結果を示したものであるが， $0.004 \%$ 之 いうきわめて低いS 含有量にもかかわらず, 初晶粒界, セルあるいはセル樹枝状晶境界において が認められるのである。

\section{3-5 P の影整}

低炭素鋼においてC含有量が0.13\%以下の之きには， 凝固割れにおよぼす Pの影響はSに比して無視できると 考えられている7. 実際, 著者らも第 5 報伛おいて Trans.Varestraint 試験法によりそのととを確認した. しかし $0.13 \%$ 以上Cを合有する炭素鉿では Pの勃果は 無視できなくなるすのと考えられている7．いっぽう $\mathrm{Ni}$ む, Cと同様にPの分配係数の小さい 7 相の安定化元 妻であることを考えると，Pの悪影響を助長するすのと 考えられる，上くに $\mathrm{Ni}$ は低融点燐化物 $\mathrm{Ni}_{3} \mathrm{P}$ を形成す るため,その効果のいちじるしいことも予想されるので ある.しかし Pの効果についてはまだ十分に明らかにさ れていない，そとで Pの効果についても一部檢討を行な った.

その結果を Fig. 9 に示す. Fig. 9 は Ni およびCレ ベルの異なる 3 種類の系列の材料について， $\mathrm{P}$ 量と付加

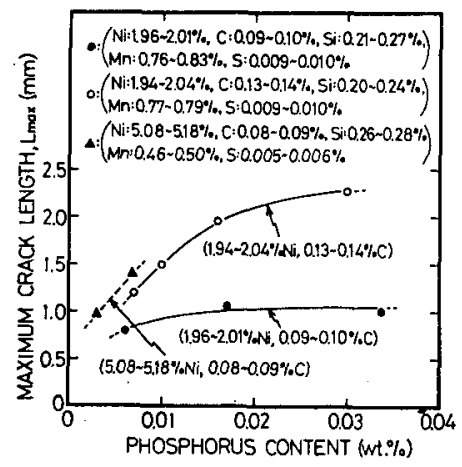

Fig. 9 Relation between phosphorus content and maximum crack length.

ひずみ $4 \%$ 時の最大割れ長さとの関係を示したあのであ る. 他の元素量は図の上部に示すように各系列ではほ之 んよ゙同一である.Fig. 9 によれば○印で示した $2 \% \mathrm{Ni}$ ，

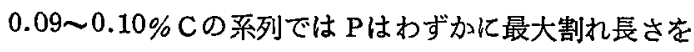
增加させるのみで，その程度は非常に小さい，しかし○ 肞で示した $2 \% . \mathrm{Ni}, 0.13 \sim 0.14 \% \mathrm{C}$ の系列，ならびに $\Delta$ 印で示した $5 \% \mathrm{Ni}, 0.08 \sim 0.09 \% \mathrm{C}$ の系列では最大 割れ長さは P量の増加とともにいちじるしく嬶加してい く.とくに0.01\%前後で効果が大きく，0.03\%付近では 
最大割れ長さはやや飽和してくる傾向にあるようであ る.

また Fig. 9 で Pの影響の非常に小さかった系列

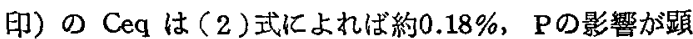

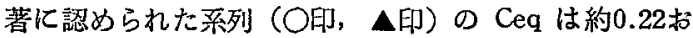
よび $0.30 \%$ ある。したがってPの影響は約 $0.2 \%$ 以上 の Ceq をむつ溶接金属において顕著になるすのと思わ れる.

そこで Ceq の高い材料では P の許容限界量が問題と なるが，Fig. 9 では $0.01 \% \mathrm{P}$ 以下のデータ数が十分で はない、いっぽう前報1で Fe-S-Mn-Ni 系合金 (Ni : 2 10\%) ならびに Fe-S-Mn-C 系合金 (C : 0.2\%)の 凝固割れ感受性を検討した結果によれば，Mn 量を增加 させるととにより疑固割れ感受性は $\mathrm{Mn}^{3} / \mathrm{S}$ が 6.7 以上 の Fe-S-Mn 系合金と同程度にまで低下したが，てれら のP含有量は $0.002 \sim 0.004 \%$ あった。 したがって，乙 のととならびに Fig. 9 の結果より，P の許容限界量は $0.005 \%$ 程度であると考えられる．すでに述べた Fig. 7 で $\mathrm{P}$ 量を $0.005 \%$ 以下に制限したのはての理由による。

さらに，Fig. 7 の結果によればSの悪影響を防止する ために必要な Mn 量は従来の常識に比しやや多いが, $\mathrm{Mn}$ む $\gamma$ 相安定化元素でありさ引に低融点燐化物 $\mathrm{Mn}_{3} \mathrm{P}$ を形成するてとを考えると，Mnも Pの悪影響を助長す ることが考えられる。乙れに関連してCを約 $0.25 \%$ 含有 するサブマージアーク溶接金属に竹いて Mn 含有量を 約 $1.5 \%$ \%上に增加させる之凝固割れ感受性がふたたび 増大すること，そしててのとき $\mathrm{P} の$ 偏析の増加している ことが報告されている10).

これらのことより $\mathrm{Ni}$ 入り高張力鋼ではとくに $\mathrm{P}$ 含有 量にす注意を払う必要があるすのと考えられる。

\section{3-5 Si, Cr, Mn およびその他の元素の影響}

一般飞高張力鋼は上記元素の他に， $\mathrm{Si}, \mathrm{Cr}, \mathrm{Mo}$ およ び鋼種によっては $\mathrm{V}, \mathrm{Cu}$ などを含有している。このう ち Cr は Table 1 に示したように多いすので $1 \%$ 近く 含有しているが．従来の報告1112)によれば約 $2 \%$ 以下の $\mathrm{Cr}$ は凝固割れにはほとんご影響をおよぼさないようで あり，本研究でも Cr の影響はとくに認められなかっ た. また $\mathrm{Si}, \mathrm{Mo}, \mathrm{V}, \mathrm{Cu}$ についてす，含有量がわずか でありててれらの影響もとくに認められなかった。

\section{4. 結言}

種々の寒用ならびに式作の溶接用高張力鋼級 (50〜100 $\mathrm{kg} / \mathrm{mm}^{2}$ 級) を用いて，その溶接疑固割れ感受性におよ ぼす $\mathrm{S} ， \mathrm{Ni} ， \mathrm{C}, \mathrm{Mn}$ および $\mathrm{P}$ 影響について検討を行 なった．得られた結果を要約するとつぎのとおりであ る.
1） S は， $0.005 \%$ 程度の低い含有量においてる，凝 固割れ感受性をいちじるしく増大させる効果をもってい る.

2） $\mathrm{Ni}$ およびCは $\mathrm{S}$ (および $\mathrm{P}$ ) の悪影響を助長して 凝固割れ感受性をいちじるしく增大させる，そして Ni とCは凝固割れ感受性に対して加算的な勃果をむってお り，その効果は次式で示す炭素当量（Ceg）に上りほ 整理できるようである.

$$
\mathrm{Ceq}=\mathrm{C}+1 / 23 \cdot \mathrm{Ni}(\mathrm{wt} . \%)
$$

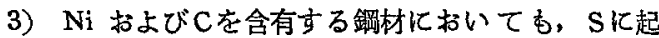
因する凝固割れ感受性は Mn 含有量を增加させることに より低下させることができる，そして必要な $\mathrm{Mn}$ 量は前 報で理論的に検討した值とよく一致するととを確認し た.すなわち $\mathrm{Mn}^{5} / \mathrm{S}>310 \sim 560$ を満足するように $\mathrm{Mn}$ を含有させれば凝固割㣗感受性はかなり低下する，とく に $\mathrm{Mn}^{5} / \mathrm{S}=2500$ ３600 程度にまで $\mathrm{Mn}$ を含有させれ ば，凝固割れ感受性はさらに低下する。

4） $\mathrm{P}$ は，Ni（おょひび）をある限界以上含有する鋼 材では，凝固割れ感受性を非常に増大させる，その限界 は，上式の Ceq を用いれば，大略 $0.2 \%$ 程度と思われ る.そのためこのような鋼材では $\mathrm{P}$ 含有量を約 $0.005 \%$ 以下に制限することが望ましいものと考えられる。

終りに，本研究で使用した材料は日本溶接協会，住友 金属中央研究所ならびに神戸製鋼所より提供を受けた。 こてに厚く御礼を申し上げる。また実験に御協力いただ いた大阪大学大学院生, 西野俊一 (現在関西䉓力勤務), 中田一博両氏に御礼を申し上げる。

\section{参 考 文 献}

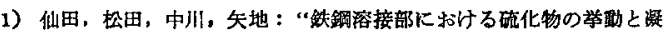
固制丸（第 7 報)"，本薣 Vol. 43 (1974)，No. 9. 揭载予定

2) W.F. Savage fand C.D. Lundin: "The Varestraint Test", Weld. J., Vol, 44 (1965), 433s - 442s.

3）仙田，松田，高野，渡边，小林，松坂：“Trans-Varestraint 試

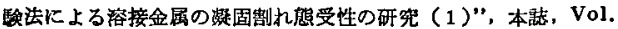
41 (1972), pp. 709 723 .

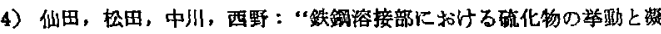
固割九(第 5 報)"，本誌，Vol. 43 (1874)，pp. 57〜65.

5）田中：“最近の铁一宸而系平衡状热图についてて，鉄と鋼，Vol. 53 (1967), pp. 1586 1604.

6) A. HELLAWELL and W. HUME-ROTHERY : "THE CONSTITUTION OF ALLOYS OF IRON AND MANGANESE WITH TRANSITION ELEMENTS OF THE FIRST LONG PERIOD", Phil. Trans, Roy. Soc., Vol. 249 (1957), pp. $417 \sim 459$

7) J.C. Borland: "Suggested Explanation of Hot Cracking in Mild and Low Alloy Steel Welds", BritishWeld. J., Vol. 8 (1961), pp. 526 540.

8) W.K.B. Marshall: "A Note on the Relationship between Chemical Composition and Hot.Cracking in Mild and Alloy Steels", British Weld. J., Vol. 7 (1960), pp. $451-453$.

9）和田：“溶接における凝固逼程とそれにともなら化学反沈”，本㩆 
Vo1. 36 (1967), p. 319 .

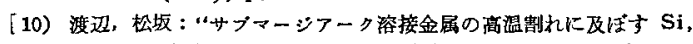

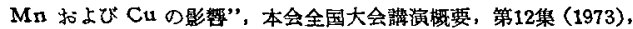
pp. $54 \sim 55$.

11) P.W. Jones: "An Investigation of Hot Cracking in Low.Alloy Steel Welds", British Weld. J., Vol. 6
(1959), pp. $282 \sim 290$.

12) F. Matsuda and W.F. Savage: "Effect of Individual Alloying Element on Weld Hot-Cracking of Two Low Alloy Steels", Tech. Rep. Osaka Univ., Vol. 19 (1969), pp. $467 \sim 491$.

\section{次号予 告}

\section{論 文}

FRPE の緎維補強効果之溶接部の挙動

$\{$ 木村 博

異種アルミニウム溶接金属中の溶質の分布之凝固組織

坪川 正和・芝野 晴男

溶接部ならびに鉦物の透過線写真にあらわれる影 (4)

迎 静雄 ・ 加藤 光昭

フラッシュ溶接部の脱炭層の生成条件および それか疲れ強さに㕲よばす影響

渡辺 統市・白沢 秀則

薄い母板の温度上昇についての瞬時発琴の 直楾熱源と移動点熱源との比較考察

建築鋼構造継手の各種溶接方法における 溶接割れの研究 $(1)$

浜崎 正信 ·松岡 敏

溶接金属の靱性におよぼす凝固相の影響( 2 (

安藤 弘平.大津 有史

非鉄クラッド鋼の接合境界部における 相互抎散に関する研究 (1)

$80 \mathrm{~kg} / \mathrm{mm}^{2}$ 級高張力鋼の被覆アーク溶接 における变形亡残留応力

\{中山 浩 - 松本 正已

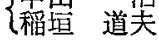

益本、功・尾崎 憲弘

進藤 弓弦・吉野 勇一

立川 逸郎・小田 勇

尔園裕三

凟 料

点熱源を与えた場合の母板の泠却速度・

安藤 弘平

鋼構造物における溶接欠陌の発生之成長に 関守る研究の現状と問題点 